\title{
Transforming theological education is not the accumulation of knowledge, but the development of consciousness
}

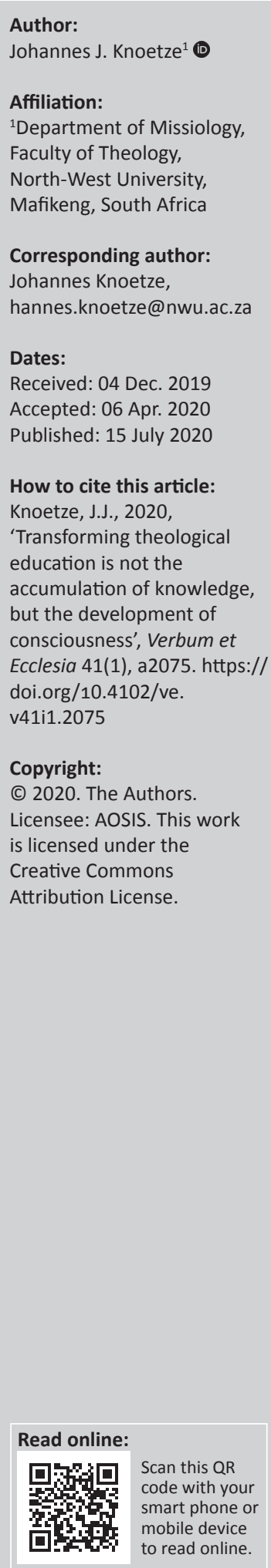

A missional diaconal ecclesiology as well as teaching and learning excellence necessitated transforming theological education towards consciousness in an age of uncertainty. The article attends to the discourse of transforming theological education, defining the concept transforming, and asks the question of transforming towards what. In the discussion on transforming theological education, we need to be conscious of the different stakeholders, for instance the higher education institution, the church, the socio-economic context of the student, the 'calling' of the student and the Trinitarian God. In this instance, we also need to be conscious of the factors that influence different and new understandings of theological education like decolonisation, globalisation, and diversity in culture, religion, worldviews, theology and even Christianity. Within the South African context, it is true that the four remaining theological faculties have in the past been and still are in partnership with the mainline Reformed (Afrikaans-speaking) churches. Currently there is a new realisation that these faculties need to accommodate Independent and Pentecostal churches if the church wants to further influence South African society and the faculties want to continue as faculties of theology (and religion). Conscious of our calling, it is realised faculties are servants in the kingdom of God and therefore they will have to attend to accessibility, decolonisation of our curriculum and globalisation to address the needs of the previously disadvantaged churches. It is along these lines that the article argues that transforming theological education is not the accumulation of knowledge, but the development of consciousness.

Intradisciplinary and/or interdisciplinary implications: The article challenges the theological education and curriculum in different ways. Intradisciplinary - the principles cover all six theological disciplines. Interdisciplinary - focus on education and social sciences.

Keywords: South Africa; Faculty of Theology; transforming theological education; worldview; contextual consciousness.

\section{Introduction}

This article is written from a South African viewpoint, where the relevance of the church as well as the ethicality of the church are questioned, due to unbiblical ministerial practices such as spraying congregants with insecticide, drinking petrol and eating snakes and rats. A burning question is why people are participating in these kinds of ministries. Does the mainstream Christian ministry not address their needs? This brings us to the place of theological education in society, since theological education in South Africa is mainly based on the premises of the West and the North and as such dominating ministerial formation in (South) Africa. The book Contested issues in training ministers in South Africa (ed. Naidoo 2015) focuses on structural realities of theological education, challenges in ministerial formation and new developments. Aware of all such realities and challenges, this article will argue for transforming theological education through contextual consciousness.

In developing consciousness of different aspects influencing theological training, we first need some clarity on our understanding and interpretation of 'transforming'. 'Transforming' can be used as an adjective describing 'theological education'. In this case, theological education is understood as an enterprise that transforms reality. Understanding 'transforming' as an adjective, we need to be conscious of the reality of the South African context, but if we want to transform society we also need to be conscious of the reality of the Trinitarian God and how we understand and interpret his presence in society. 
Alternatively, 'transforming' can be understood as a present participle, the activity of transforming of which 'theological education' is the object. Here theological education is not the enterprise that transforms reality, but something that is itself being transformed. In this instance we need to be conscious of the factors that influence different or new understandings of theological education such as diversity in culture, religion, worldviews, theology and even Christianity.

Theological training is not only about transferring information, but also requires critical engagement with what is known, is needed in order to transform the knower, and create a responsibility towards what is known. (Cloete 2015:151)

We also need to take cognisance of practical factors such as accessibility to accredit theological institutions. In this article, both these understandings will be discussed.

Since theological education has to do with the revelation of God through the Bible, it is important to be conscious of the way in which we interpret the Bible. For this article, the Bible will be read and interpreted from a missional perspective. In his book The mission of God, Wright (2006:39) describes missional hermeneutics as at least recognition of the multiplicity of perspectives and contexts from which and within which people read the biblical texts'. He indicates how the whole Bible focuses on God's mission and how the Bible is not written to provide us with information but is written for our transformation and participation in God's mission. Wright also argues that the church does not have a mission, but that God's mission has a church.

In developing a missional hermeneutics, there are at least three important ways in which it will influence or transform theological education. Firstly, missional hermeneutics will influence the way we think about the church, our ecclesiology, who is the mother or the bearer of theological students. Secondly, our ecclesiology will influence the curriculum and the way we teach our students, since we want to deliver a 'product' that will participate in the missio Dei. Burger (2017:24) describes missional as the church serving the community outside the church and the country as a whole. It includes missions and evangelism far away but focuses on our immediate context and social issues, such as racism, poverty and social justice. Thirdly, a missional ecclesiology focuses on the local congregation and its calling. Being conscious of this 'new' ecclesiological understanding, ${ }^{1}$ theological education needs to deliver students who are spiritual leaders and who are able to act as 'change agents' in local societies.

Having discussed the way in which we interpret the Bible, we also need to be conscious of how the context has changed. In his book Engaging globalization, Myers (2017) indicates how globalisation was always part of the missio Dei. Knoetze (2012) also argues that migration of people is part of God's 1.The word 'missional' surfaced in the South African church vocabulary only after 1998 (Burger 2017:20). missio Dei, and not something new to God. Globalisation has changed the African context in direct and indirect ways. From an African perspective, globalisation is experienced and described in a negative sense as colonisation. Within the higher education context in South Africa, the concept of decolonisation and the implications thereof are vigorously debated.

The church needs to attend to the 'new' societies she finds herself in. Together with globalisation and migration, Christianity has moved from the North and the West to the South and the East, and now back again. Writers such as Oduro et al. (2008) and Bediako (1995) see the rapid growth of the church in Africa as rather problematic due to a lack of theological integrity. Much of this growth happens through the African Independent/Initiated Churches (AICs), which range from churches with a biblical foundation to churches that are founded in the African Traditional Religion, without any biblical foundation. One of the challenges for theological education in (South) Africa is the theology that is practiced in some of these churches, through people whose ministerial skills are not reconcilable with ministry as found in the Bible.

Being conscious of the decolonisation debate and being painfully aware of how theology was misused in the past (and is still misused in the present) to influence societal structures, we need to listen to the new voices from the South and the East. Bosch (1991:226-230) indicates how colonisation and the mission from the West were entangled. The World Council of Churches (Keum 2013), in the document Together towards life, argues that the church should listen to the voices from the margins, meaning those who are not heard in everyday society: the poor, the weak, orphans, women et cetera. This indicates that theology and theological education cannot be practised from a position of power but needs to empower people to live in this day and age.

This raises the question whether theological education can and should be provided by higher education institutions (HEIs), which are in a power position and are mainly run and influenced by economics and politics. Unfortunately, we do not have the space to argue this in depth and it is not the purpose of this article, therefore just a few remarks to keep in mind. This author believes, in short, that the answer is yes, theology should be taught at HEIs, for the following reasons. Many of the famous HEIs were initiated and started by the church. This is true all over the world but especially in Africa and South Africa. Theology has the calling to empower, and it does so together with and by influencing other academic disciplines. Theology is an integral part of the academic world, and as a science (Erickson 2001:18) needs to play according to the same scientific rules as other sciences if it wants to keep its integrity and influence society. However, thinking about theological education stakeholders such as HEIs, Bible schools, churches, and denominations need to be conscious of the fact that theological education needs to be more accessible to previously disadvantaged people in (South) Africa. Currently the Faculty of Theology at the 
North-West University has initiated different modes of delivery such as contact learning and open distance learning, and is now moving to online learning to make it more accessible. The Faculty of Theology has also developed new pathways into the higher education system through higher certificates, diplomas and postgraduate diplomas. Within theological education it is important to realise that the concept of God's kingdom refers not only to God's sovereignty but also to the community of those participating in the missio Dei. The kingdom of God is a learning community with gifts of life, liberation and love.

In the discussion on transforming theological education, we need to define transformation and ask the question: Transformation towards what? Thus, we need to look at the context from which we speak. Within the South African higher education context, the four remaining theological faculties at the University of Pretoria (UP), North-West University (NWU), University of the Free State (UFS) and Stellenbosch University (SU) have been and are still in partnership with the mainline Reformed churches. Currently there is some realisation that the faculties need to open up to Independent and Pentecostal churches.

Bosch (1991:192-194), describing the church and its context, might help us to interpret the present based on history. He explains that early Christianity had to defend itself on two fronts: against Judaism and against Hellenistic religions. Today we need to recognise the positive as well as the negative influences of both worldviews, religions and cultures as well as our own and other worldviews and cultures on present-day Christianity. According to Bosch (1991:193), the problem with Christianity within a multireligious and multi-cultural world was not the dissimilarity but the similarities. A certain understanding of Christianity could easily fit into the mould of another religion without any claim of transformation on either of the religions. The general spirit of the time then, just as in our globalised world today, 'was conducive to an almost boundless syncretism of oriental and occidental religions' (Bosch 1991:193).

Two other factors that transformed Christianity was when the new tradition of the sophisticated Christian scholar was introduced and Christianity became the bearer of culture and a civilising society (Bosch 1991:193). Especially the latter became and still is a major influence on Christianity in (South) Africa, especially when it comes to theological education (Brunsdon \& Knoetze 2014:267). During the period of colonisation, mission was in many instances transformed from bringing the Good News to bringing superior culture and education to inferior people (Bosch 1991:448). The second important transformation that Bosch (1991) describes is the slow disintegration of the pagan empires:

Fatalism was widespread among the populace, who attempted to find security against the vicissitudes and confusions of life resorting to magic and astrology ... Christianity was ready to fill the vacuum - and the citizens of the Empire responded. (p. 193)

Within the context of globalisation fatalism, confusion and insecurity are experienced in many instances. However, it seems as if theological education is not fit to help fill the possible vacuums because it is identified as the bearer of a culture, known in Africa as colonisation, and it is still mainly focused on Western theology (Brunsdon \& Knoetze 2014:261).

\section{Consciousness of worldviews}

It is acknowledged that the mere distinction between Western culture, majority world culture and global culture is a very simplistic and generalised point of departure in the discussion of contextualised theological education. However, it will become clear why it is important for this discussion. Many researchers have applauded the fast-growing church in Africa, but then raise the concern of the shallowness of the theology. Moon (2017), in his book Intercultural discipleship, discusses how the Western theological worldview has put discipleship or spiritual growth in Africa into a straitjacket without knowing it. At theological institutions in South Africa, we empower students with good theological knowledge, but we never take them through a formal discipleship programme. According to Moon (2017:5), a factor contributing to this is the modern and postmodern Western culture vs the majority world culture (see Table 1). However, the author would like to add a third view, which is already identifiable but is still developing, namely global world culture.

In the rest of the article, the different topics listed in Table 1 will be discussed.

\section{Learning}

Within HEIs in South Africa, there is a definite move from a printed learning and class teaching context to an e-learning

TABLE 1: Comparison of cultural assumptions

\begin{tabular}{|c|c|c|c|}
\hline Topic & Western culture & Majority world culture & Global world culture (Hypothesised) \\
\hline Learning - How? & Print learning preference & Oral learning preference & E-learning \\
\hline Assessment - What? & Testing knowledge & Testing competence & Skills and application \\
\hline Identity - Who? & Individual identity & Collective identity & Social (glocal) identity \\
\hline Orientation regarding $\sin -$ Who? & $\begin{array}{l}\text { Justice (guilt) orientation } \\
\text { Individualistic/personal }\end{array}$ & Honour/shame orientation relational & Honour/shame orientation personal \\
\hline Focus - What? & Cognitive focus & Emotive focus & Egoistic focus \\
\hline Reality - How? & Material/scientific reality & Spirit-power reality & Virtual reality \\
\hline Production of ministers - How? & Assembly-line production & Handcrafted production & Socially crafted production \\
\hline
\end{tabular}

Source: Adapted from Moon, W.J., 2017, Intercultural discipleship: Learning from global approaches to spiritual formation, Baker Academic, Grand Rapids, MI. p.5. 
environment, mostly because the current infrastructure cannot accommodate the number of students after the \#feesmustfall campaign. None of the above learning methods are less valuable or wrong, just different. Individually they are just not sufficient within a pluralistic modern and postmodern society. Learning in the digital age requires 'a new culture of learning' which may also be described as self-directed learning (SDL). Self-directed learning takes place when students take ownership of their own learning process, determining their learning needs, identifying the learning outcomes, selecting the learning strategies, and evaluating the learning performance and outcomes. Living in the glocal (global and local) culture, it is in a sense easier with e-learning to combine oral and printed learning material, by uploading documents, making videos, creating chat rooms, et cetera and to let students manage their own studies. Unfortunately, in many rural areas far away from theological institutions, there is a lack of infrastructure and resources to work electronically.

In the (South) African context, we also need to be aware of the digital readiness of people to participate in e-learning. Even if we focus on the emerging adults (15-24 years of age), also known as a generation of 'digital natives', it is true that many of them, especially in rural areas, have never seen or used a computer. In Africa, 'digital natives' rather refers to mobile and smartphone users (Knoetze 2017:5). Higher education institutions are currently working hard towards making e-learning courses available on mobile and smartphones.

As theological education relates closely to spiritual formation, it is noted that in the Old and New Testament learning was not an academic exercise, but rather the following of a rabbi (teacher) (Mt 9:14; 22:16; Jn 9:28) called discipleship. When Jesus was on earth, He taught in the same way: his disciples (learners) were to follow him, walk with him, learn from his actions and teachings, and obey his instructions. In this way the disciples and their worldview were transformed. Instead of attacking and destroying an old or wrong worldview, Jesus help his followers to engage in a different worldview through the genres available in the existing cultures. This is the goal of transforming theological education; to create a new way of living, 'to transform the worldview, not simply to learn new beliefs or behaviours' (Moon 2017:46).

How then can e-learning or online learning contribute to theological education? The electronic environment takes us out of the comfort of our well-established views of print learning or oral learning and challenges us with more advanced and combined ways of learning. Theological learning within the glocal world is not necessarily about new beliefs and behaviours, but about a new consciousness of the glocal context and the application of biblical beliefs and behaviours in this context. Learning in this context has more to do with soft skills (a changed worldview) than with new facts.

\section{Assessment}

One of the statements in the NWU Teaching, Learning and Assessment Policy (TLAP 2019) reads:

$[T]$ o offer innovative quality teaching and learning with a view to produce graduates endowed with the knowledge, skills and competences that will help address national human resource, economic and development needs and contribute towards the building of a skilled and capable workforce and sustainable communities. (p. 1)

Attending to assessment as mentioned in Table 1 above, it becomes clear from the above that the NWU wants to assess awareness and inclusiveness of different worldviews and different assessment methods - the Western worldview testing knowledge, the majority world culture testing competence and global world culture testing skills and application of knowledge and competence. In an online environment it is easier to assess knowledge and skills in the most appropriate way for the candidate, be it a written or oral (recorded) exam, or even a practical (video-recorded) exam testing skills and competencies. However, within the theological education environment we still need to rethink assessment as part of learning and more specifically SDL. Within the South African context, it might be problematic due to the lack of access to computers and data in rural areas.

\section{Identity}

Identity has to do with the self (individualistically) as well as the way we relate to the world or society we live in (collective identity), and how we relate to God or a supreme being (spiritual identity). Within the context of theological education, we need to be conscious of the individual's calling (spiritual identity) as well as the faith community from which the student came (collective spiritual identity). 'Therefore, identity can be understood according to self-definition and/ or as a particular form of social representation that mediates the relationship between the individual and the communal world' (Knoetze 2017:2). Being aware of the individual's contextual identity, we also need to be conscious of the general worldview of the people from which the student comes (Knoetze 2017):

In Africa, identity is not primarily determined through individualistic assets. It is a matter of 'I participate, therefore I $\mathrm{am}^{\prime}$. Best described by the Ubuntu principle of 'I am only because we are, and since we are, therefore I am'. Descartes' famous statement 'I think therefore I $\mathrm{am}^{\prime}$ may best describe the individualistic understanding of identity in a modern (South) Africa. However, from a [b]iblical humanity as well as discipleship perspective, this article wants to define identity with the statement: I am and you are, because he (God) is. (p. 1)

Individual identity is created by personal perceptions and accomplishments. Using printed learning preference, students are taught to work independently and do their own work. From a Western perspective, there is also a greater focus on the personal relationship with Jesus Christ than the collective identity of the faith community in Christ. The collective identity in the majority world focuses more on the 
immediate clan. The African principle of ubuntu is a good example of this. Using Africa as an example of the majority world, identity within Africa is found through certain rituals, like initiation, and symbols, like totems and even clothing (church uniforms).

Within the global culture, identity is constructed online through profiles. The integrity of a profile in many instances relates to social acceptability, which might not always be a person's authentic identity. Although all identity is socially constructed, the main difference between collective and social identity is that in the global electronic world the collective or social society might be from all over the world, and not only locally defined. It is therefore important to realise that the identity of transforming theological education will not be a bounded set (determined by a set of boundaries that needs to be passed) but from a missional perspective it will be more discipleship oriented and more a centred set. This means that, ' $[u]$ nlike bounded sets, which are defined by the distance from the centre, centred sets are determined by the direction of the movement' (Moon 2017:47).

Bevans (2018) talks about a Christ-connected discipleship which not only involves a personal connectedness to Christ 'but also to be connected to Christ by walking the same walk that He walked', in the Spirit (Bevans 2018:366). When discipleship is understood as a call to mission, discipleship becomes transforming discipleship, and will then participate in all acts 'toward the eradication of any injustice, slavery, discrimination, exclusion, greed, and violence' (Bevans 2018:367). As suggested earlier in this article, the centre of transforming online theological education is focused on working towards the coming of the kingdom of God, applying those principles in this world. This consciousness of transforming theological education will transform worldviews when biblically faithful principles and culturally relevant responses are applied to issues attempting to move the focus away from the kingdom of God. A Christconnectedness will help to overcome the dangers of syncretism and spirit-level Christianity.

To create a transforming theological identity in the global culture, we need to understand the missional theology as described by Wright (2006), and keep to the belief that ' $[w] \mathrm{e}$ do not bring God to a culture; rather, God brings us to the culture' (Moon 2017:51). Making use of relevant and known proverbs, stories, music, we need to create an online 'ongoing set of intentional activities governed by the goal of initiating people into the kingdom of God through appropriate instructions, experiences, symbols and ceremonies' (Zahniser 1997:23 cited in Moon 2017:53), to form an online theological identity.

\section{Orientation regarding sin}

In justice-oriented cultures (usually the Western cultures), a uniform set of rules are used for all people in society regardless of role and position to ensure that all people are treated equally and fair. Regarding the view on sin within Christianity in Western cultures, the individual must confess his or her sin to God in order to receive forgiveness based on the cross and resurrection of Jesus Christ. This results in restoration for the sinner. In honour-oriented cultures, people are bound together by relationships and are expected to act according to the expectations of their own in-group. Sin is therefore not (in the first place) seen as an offence against God or aggression of moral law or virtue, but a breakdown of relationships within the community, which brings about shame, suspicion, jealousy and hostility (Nurnberger 2007:27-28). Within an African worldview, this community always includes the ancestors. When an individual sins, it brings shame to the in-group; the only way the person can restore purity or be freed from the shame is through specific rituals that will erase the shame or impurity and restore relationships.

Moon (2017:9) argues that problems and misunderstandings occur when people from justice-oriented cultures engage with people from honour-oriented cultures and vice versa. This brings us to what Myers (2017) and others call the 'missing middle'. Within current theological education, attention is not given to the real spiritual questions of African people, such as healing and witchcraft. The meaning of salvation in the majority world culture is much more inclusive than in the Western culture. Within the global culture of the electronic media there is no way that all people are treated equally, fair or with the same understanding of sin. Although social media might be viewed as an honouroriented culture, it is totally different from the majority world culture, since there are no ethical framework and no condemnation. The honour-shame culture on social media is different from the majority world honour-shame culture, since on social media it has more of a personal focus. Individuals are more likely to be honoured or shamed, which might link more to the individualistic view of sin in the Western world. Where there are social online communities, a community will just 'unfriend' a sinner and leave him or her in the dark. The real danger here is to create communities also faith communities - that think, talk and believe the same without any critical reflection.

\section{Focus}

In the introduction, mention was made of the fact that theological education consists of three important aspects, namely theological or biblical knowledge, ministerial formation and spiritual formation. In Western culture and from the perspective of modernity there is a clear focus on the cognitive. This is no different in theological education at the HEIs in South Africa. The focus of (reformed) theological education in South Africa at UP, UFS, SU and NWU is currently mostly focused on the cognitive, although the UFS and SU make specific reference to spiritual formation in their curriculum (Hoffman 2015:87). Hoffman reminds us that ' $f$ f or theology to be intellectually rigorous, spiritual formation plays an important role' (2015:91). Most current 
theological students in (South) Africa come from the majority world. Many authors have indicated that African people are spiritual in many ways and understand and interpret life from a spiritual perspective (Mbiti 1991; Nurnberger 2007). Therefore, a Christ-connected spiritual formation is of the utmost importance in theological education.

According to Table 1, the majority world culture focuses more on the emotive, which might in this instance also be translated as the spiritual. Because of the strong focus on knowledge (alone) in current theological education at HEIs in South Africa, ministers from the African context do not always feel equipped to address the specific spiritual needs of African people. For most Africans with a holistic worldview there is no clear distinction between the spiritual world and the physical world. It is not enough for them to know the correct theological answers, they want to experience the truth. The truth will only prevail where theological intellect is practised within the context of God's love and the love of the faith community. Therefore, theological education has to attend to spiritual formation, which is understood as the integration and interdependency of the intellectual, psychological, social, cultural and spiritual dimensions of life' (Hoffman 2015:87). Spiritual formation is a lifelong process that has already begun in the faith community, family and school the student comes from, before she or he enrolled for formal theological education.

The hypothesis in this article is that the focus in the global world culture is self-centric. This is also clear in the lives of most of the pastors in Africa preaching the prosperity gospel, where it is about their personal enrichment. In the globalised culture there is a clear focus on the ego, or the self of companies and individuals; this would include both the cognitive and the emotive sides. Egoism holds a danger for both the institution and the student, and thus extra precautions need to be taken since Christ-connected spiritual formation is against egoism. Hoffman (2015:95) argues that spiritual formation can take place through distance learning. We might therefore accept that spiritual formation is possible in an environment of online or electronic social platforms. Within the online environment, work is more ecumenical and the question arises whether it is possible to do 'generic spiritual formation'. As argued previously, spiritual formation is interdependent and builds on theological knowledge. If a theological HEI has the 'institutional will' to integrate spiritual formation into theological education, it needs to also state the theological paradigm based on which it teaches theology. If there is no 'institutional will' towards spiritual formation, academic staff will see academic formation as their main responsibility and spiritual formation will become the hobby or the responsibility of an interested few.

What then should the focus be for online 21st-century theological training? Among the different definitions of spiritual formation discussed by Hoffman (2015), the concept and the role of community in spiritual formation should be noted. Spiritual formation can only take place within a faith community. To move away from the egoism of the global world culture and the individualism and dominance of Western theology, it is important to create an online community across cultural and denominational borders with a clear theological paradigm. This poses a challenge to HEIs who want to engage in online or distance education.

\section{Reality}

According to Jenkins (cited in Moon 2017:11), the key area that divides northern and southern hemisphere Christians is the matter of spiritual forces and their effect on everyday life. Within the material or scientific worldview, the Bible is used to discover incontrovertible truths that are systematised into doctrines of God, humanity and church. Nurnberger (2007:254-255) argues that in Western culture we have become the victims of our own interests and desires and that human life is crippled in our relentless pursuit of material gain. Van't Spijker and Visser (eds. 2018:8) describe Western culture as a culture that bid Christianity farewell. This is also noted with the movement of Christianity from the North and the West to the East and the South, known as the majority world culture. Within the majority world culture, Spiritpower is the reality. Bediako (1995:106) writes ' $[p]$ rimal religion deals with a source of power, while Western theology has centered on a system of ideas'. Nurnberger (2007:252) describes God as the source of all reality, but mentions that 'the God of conventional Western Christianity is "too small a God"' to address the needs of the majority world culture. Africans need a theology that will protect them from witchcraft, sickness and other curses.

Within the global culture, we find both the aforementioned realities - the material reality as well as the spiritual-power reality - but in many instances also the creation of a false reality. Cloete (2015:143) highlights the fact that technology is more than just a tool; it also represents a culture. Technology is not used in the 21st century because it has proved to enhance student learning 'but because internet communication technology (ICT) is a generator of contemporary culture' (Cloete 2015:144). In many instances a virtual-idealistic reality or life is created away from everyday reality. Some people create these realities to escape the responsibility of dealing with everyday reality. In discussing the disembodiment of educational technologies, Cloete (2015:149) alludes to the increased possibility of irresponsible conduct of students. Another important question asked is: '[C]ould it be that theology students could unlearn the art of being present with people?' This question underlines the importance of engagement with the reality of the local context of the student.

The reality of the virtual world of online theological training opens up different possibilities but also raises new questions. Firstly, in the 21st century context, we can assume that technology will become more important in theological training since students live in a world filled with technology. 
Although technology enhances accessibility, it might also discriminate against the marginalised, especially in rural areas where technological resources may be limited. Secondly, the new paradigm will cause uneasiness with academic staff and some students because of the 'quantification of knowledge and the minimised responsibility on the side of the knower' (Cloete 2015:151). Theological education in the global culture is transforming the knower as well as the student, creating a (new) responsibility towards what is known. In this sense, teachers and students are at the same level within the global world, reducing the role of the teacher to transferring and interpreting knowledge, creating more opportunities for SDL. As such, the virtual reality 'creates a complex process that facilitates meaning-making - not only of theory, but also of the self and the world' (Cloete 2015:153). This meaning-making brings us to the different theological understandings.

\section{Theology}

Globalisation and the global world culture have changed our theologies and theological understandings dramatically. When the centre of Christian gravity was in Europe, the European missionaries took the reformed theology, with a focus on personal redemption, to the majority world cultures. Redemption theology is focused on Jesus Christ as the only saviour of the world and the need for conversion. 'When conversion does take place, it means that certain religious absolutes are deemed higher or superior to others, which in the religion of pluralism is wrong' (Turaki 2001:7). The belief in Jesus Christ as the Messiah has a transforming impact on culture, religious worldview and society. Within the majority world culture, the focus is on creation theology in which there is recognition of a creator. The creator is different for different religions and usually includes plurality. This is why Turaki writes that the term African theology 'bears no specific Christian focus' (2001:3-4). He then continues to indicate that there are more attributes to God than just that He is the creator, and that Africa puts more emphasis on the attribute of God as creator, although the creation has been altered by the fall. It is in this regard that he argues that salvation and worship in Africa are based on the concept of God as creator, while biblical salvation and worship is based on both attributes of God as creator and God as redeemer (2001:206-207).

Myers (2017:201) makes the interesting comment that '[a]s the center of gravity of the church was moving to the Global South, the historic movement of people from the West to the rest of the world changed direction' - now people from the rest of the world are moving to the West. He further alerts us to the fact that the majority world Christians are generally more theologically and morally conservative than Christians in the West (2017:200). The hypothesis of this article is that we might find a syncretic theology in the global online environment. The important question is whose theology will guide us? With the powerful church based in the West, missionaries spoke of the 'three selves' as a goal for the younger churches, namely self-support, self-governance and self-propagation, but they did not envision self-interpretation or theologising. Teaching theology in an online environment with an SDL focus, might help all church denominations to engage in conversations that might lead to conversions or transforming theological education as well as the glocal context. For this kind of conversations, we need discernment from the Holy Spirit to guide us in the truth within our different contexts.

\section{Production}

While all Christians participate in theology, very few ever have the opportunity to engage formally in studying theology. In Africa, 85\% to $90 \%$ of all Christian leaders have no formal theological education (Africa Evangelical Alliance Conference 2019). Although it is recognised that all theology is contextual theology, theological education at South African HEIs does not train students for different contexts. Spiritual leaders or ministers are trained with the same curriculum whether they will serve in a middle-class Afrikaans or English congregation, in a poor African congregation in the rural area or in the central city of Johannesburg. This is called assembly line production - students are trained to become partners in a congregation of any kind. In the majority world culture, we find tremendous growth among the so-called independent churches, whether they are African or Pentecostal. Most of the ministers in the independent churches have a very specific calling or ministry that speak to a need within his or her context (Oduro et al. 2008:57-71). May this be one of the reasons these ministers or pastors shy away from formal theological education? Are they in need of a more 'handcrafted training' for their specific calling?

In the global culture, new kinds of ministries are possible. Many preachers have their own television channel; others do live-streaming of their sermons. The electronic media give ministers the opportunity to create their own ministries according to social demand, also outside of their local context. The question that needs to be investigated and answered is: Does theological education prepare ministers for the glocal culture in Africa? How should theological education transform, if it should transform to better equip ministers? Stackhouse was of the following opinion (cited in Myers 2017):

Insofar as most social analyses of that emerging global [civil society] are no longer attentive to any theological perspective, the principalities, thrones, authorities, and dominions behind and residually in them tempt scholars to cynical analysis, and the multitude follows their arrogance, idolatry and injustice. They have no fundamental basis for a reconstructive vision [of society]. (p. 220)

\section{Conclusion}

The article indicates how different worldviews and contexts influence theological understanding. It is therefore important in the development of theological curricula to be aware of the paradigm from which theology is taught as well as the context in which it is taught. In a fast and continuously changing world, it is important to preserve theological 
education at public HEIs to help theology to be conscious and adapt to the context, so that theology will be able to address the spiritual needs of people within a specific context. It is therefore argued that transforming theological education is not only about the accumulation of knowledge, but also about the development of consciousness.

\section{Acknowledgements Competing interests}

The author has declared that no competing interest exists.

\section{Authors contributions}

I declare that I am the sole author of this research article.

\section{Ethical considerations}

This article followed all ethical standards for research without direct contact with human or animal subjects.

\section{Funding information}

This research received no specific grant from any funding agency in the public, commercial or not-for-profit sectors.

\section{Data availability statement}

Data sharing is not applicable to this article as no new data were created or analysed in this study.

\section{Disclaimer}

The views and opinions expressed in this article are those of the author and do not necessarily reflect the official policy or position of any affiliated agency of the author.

\section{References}

Africa Evangelical Alliance Conference, 2019, September 8-13, Nairobi, Kenya.

Bediako, K., 1995, Christianity in Africa: The renewal of a non-Western religion, Orbis Books, Maryknoll, NY.

Bevans, S., 2018, 'Transforming discipleship and the future of mission: Missiological reflections after the Arusha World Mission Conference', International Review of Mission 107(2), 362-377. https://doi.org/10.1111/irom.12236

Bosch, D.J., 1991, Transforming mission: Paradigm shifts in theology of mission, Orbis Books, Maryknoll, NY.

Brunsdon, A. \& Knoetze, H., 2014, 'Batho Pele (People First) - Some ethical and contextual reflections on theological training in an African context', in M.A. Mokoena \& I. Oosthuizen (eds.), Nuances of teaching learning and research Research and publication book series 3, pp. 261-280, Andcork, Potchefstroom.

Burger, C., 2017, 'Why we need the missional conversation in South Africa now', in C. Burger, F. Marais \& D. Mouton (eds.), Cultivating missional change: The future of missional churches and missional churches, pp. 20-34, Bible Media, Wellington.

Cloete, A., 2015, 'Education technologies: Exploring the ambiguous effect on the training of ministers', in M. Naidoo (ed.), Contested issues in training ministers in South Africa, pp. 141-154, SUN MeDIA, Stellenbosch.

Erickson, M.J., 2001, Introducing Christian doctrine, Baker, Grand Rapids, MI.

Hoffman, L., 2015, 'Contesting spiritual formation in theological education', in M. Naidoo (ed.), Contested issues in training ministers in South Africa, pp. 85-98, SUN MeDIA, Stellenbosch.

Keum, J., 2013, Together Towards Life, World Council of Churches, Geneva.

Knoetze, H., 2012, 'Missionary diaconate: Hope for migrated people', Missionalia 40(3), 40-52. https://doi.org/10.7832/41-1-20

Knoetze, J.J., 2017, 'Who are the disciples? Identity perceptions about millennials and the church', Verbum et Ecclesia 38(1), a1718. https://doi.org/10.4102/ve.v38i1.1718

Mbiti, J.S., 1991, Introduction to African religion, 2nd edn., Waveland Press, Long Grove.

Moon, W.J., 2017, Intercultural discipleship: Learning from global approaches to spiritual formation, Baker Academic, Grand Rapids, MI.

Myers, B.L., 2017, Engaging globalization: The poor, Christian mission and our hyperconnected World, Baker Publishing Group, Grand Rapids, MI.

Naidoo, M. (ed.), 2015, Contested issues in training ministers in South Africa, SUN MeDIA, Stellenbosch.

Nurnberger, K., 2007, The living dead and the living God, Cluster, Pietermaritzburg.

Oduro, T., Pretorius, H., Nussbaum, S. \& Born, B., 2008, Mission the African way: A practical introduction to African instituted churches and their sense of mission, Christelike Lektuur Fonds (CLF), Wellington.

Turaki, Y., 2001, The unique Christ for salvation: The challenge of the non-Christian religions and cultures, International Bible Society Africa, Nairobi.

Van't Spijker, J. \& Visser, P.L.D. (eds.), 2018, Een ander evangelie? Contextualisatie in een verschuivende westerse cultuur, Drukkerij Holland, Alphen aan den Rijn.

Wright, C.J.H., 2006, The mission of God: Unlocking the Bible's grand narrative, InterVarsity Press, Downers Grove, IL. 